\title{
Safety of Uncrossmatched ABO-Compatible RBCs in Alloimmunized Patients with Bleeding: Data from Two Decades: Results of a Systematic Analysis in 6,109 Patients
}

\author{
Frauke Ringel $^{a, b}$ Helge Schoenfeld $^{b, c, d}$ Said El Bali ${ }^{b} \quad$ Jalid Sehouli ${ }^{a}$ \\ Claudia Spies ${ }^{\mathrm{e}}$ Abdulgabar Salama ${ }^{\mathrm{a}, \mathrm{b}}$ \\ aDepartment of Gynecology with Center for Oncological Surgery, Campus Virchow-Klinikum, Charité - \\ Universitätsmedizin Berlin, Berlin, Germany; 'bnstitute of Transfusion Medicine, Campus Virchow-Klinikum, \\ Charité - Universitätsmedizin Berlin, Berlin, Germany; 'Institute of Laboratory Medicine, Clinical Chemistry and \\ Pathobiochemistry, Charité - Universitätsmedizin Berlin, Berlin, Germany; ${ }^{d}$ Labor Berlin, Charité Vivantes GmbH, \\ Berlin, Germany; 'Department of Anesthesiology, Division of Operative Intensive Care Medicine, Campus \\ Virchow-Klinikum, Charité - Universitätsmedizin Berlin, Berlin, Germany
}

Keywords

Blood transfusion · Uncrossmatched · Trauma •

Incompatibility $\cdot$ Hemorrhage

\begin{abstract}
Introduction: Uncrossmatched ABO-compatible red blood cells (RBCs) are generally recommended in patients with lifethreatening massive bleeding. There is little data regarding RBC transfusion when patients are transfused against clinically significant alloantibodies because compatible RBCs are not immediately available. Methods/Patients: All patients reviewed in this study $(n=6,109)$ required emergency blood transfusion and were treated at the Charité - Universitätsmedizin Berlin between 2001 and 2015. Primary uncrossmatched $\mathrm{O}$ Rh(D)-positive or -negative RBC units were immediately transfused prior to complete regulatory serological testing including determination of $A B O$ group, Rhesus antigens, antibody screening, and crossmatching. Results: Without any significant change in the protocol of emergency transfusion of RBCs, a total of $63,373 \mathrm{RBC}$ units were transfused in 6,109 patients. Antibody screening was positive in 413 patients $(6.8 \%)$, and 19 of these patients received RBC units against clinically significant alloantibodies. None of these patients appeared to have developed significant hemolysis, and only one patient with anti-D seems to have de-
\end{abstract}

veloped signs of insignificant hemolysis following the transfusion of three Rh(D)-positive units. One patient who had anti-Jk ${ }^{\mathrm{a}}$ received unselected units and did not develop a hemolytic transfusion reaction. Conclusion: Transfusion of uncrossmatched $\mathrm{ABO}$-compatible RBCs against alloantibodies is highly safe in patients with life-threatening hemorrhage.

(c) 2021 The Author(s).

Published by S. Karger AG, Basel

\section{Introduction}

The clinical significance of antibodies to red blood cells (RBCs) is reflected by the fact that the transfusion of correspondingly antigen-positive cells may result in severe hemolytic transfusion reaction (HTR) and even death [14]. Prior to the discovery of $\mathrm{ABO}$ blood groups by Landsteiner in 1900, blood transfusion was associated with acute HTR and mortality in $50 \%$ of transfused patients. On this, experiences in this field remained largely negligible for roughly one century following the first successfully performed direct blood transfusion in 1819 [5]. During the world wars and until the introduction of separated RBC concentrates in the sixties, acute HTRs were observed in many cases due to the isoagglutinins anti-A and/ or anti-B in the used whole blood. Today, acute HTRs and related mortality are relatively rare $(1: 76,000$ and 1:1.8

\section{karger@karger.com} www.karger.com/tmh

Karger $\frac{1}{*}$

BOPEN ACCESS
(C) 2021 The Author(s)

Published by S. Karger AG, Basel

This is an Open Access article licensed under the Creative Common Attribution-NonCommercial-4.0 International License (CC BY-NC) (http://www.karger.com/Services/OpenAccessLicense), applicable to the online version of the article only. Usage and distribution for commercial purposes requires written permission.
Correspondence to:

Frauke Ringel, frauke.ringel@ charite.de 
millions, respectively) and the incidence of delayed HTRs is $\leq 1: 60,000$ [5]. To avoid HTRs, serological investigations including estimation of at least $\mathrm{ABO}$ blood group and Rhesus(D) antigen, antibody screening test, and crossmatching prior to RBC transfusions are recommended worldwide, even in countries with limited resources. The most relevant alloantibodies which may cause HTRs are directed against Rhesus, Kell, Kidd, Duffy, and less commonly against some other antigens $[1,2,6]$. In some instances, the clinical relevance of alloantibodies may remain unclear, and several tests have been described to characterize the clinical significance of such antibodies. These include the chromium-51 $\left({ }^{51} \mathrm{Cr}\right)$ and biotin label RBC survival assays $[7,8]$, phagocytosis of presensitized RBCs by monocytes, the antibody-dependent cellular cytotoxicity [9], and the so-called biological compatibility testing [10]. The gold standard for predicting the clinical significance of alloantibodies remains, however, the 1-h ${ }^{51} \mathrm{Cr}$-labeled RBC survival of transfused cells as recommended by the International Committee for Standardization in Hematology [11]. Whatever the method used may be, the occurrence and significance of HTR cannot invariably be determined. The response to transfusion of incompatible RBCs is dependent on several factors including antibody concentration and class, capacity, and state of recipient's macrophages, complement activation, amount of transfused RBCs, and most importantly, as we think, whether the transfused cells remain in the circulation of affected patients or will be lost due to the uncontrolled hemorrhage. Though the latter point plays a key role in case of massive blood loss and blood transfusion, it has not yet been considerably evaluated. The vast majority, if not all, of recommendations stress the holding rather than transfusion of incompatible RBCs, even in emergency cases and life-threatening blood loss [12-17]. Based on our experience, detectable alloantibodies should not represent a contraindication in patients with massive bleeding as long as bleeding has not been stopped. In this study, we present the data of a large patient cohort and discuss relevant literature publications.

\section{Patients and Methods}

All patients presented here had massive bleeding and urgently required (massive) blood transfusion consisting of uncrossmatched $\mathrm{ABO}$-compatible RBCs and other blood products (Table 1). Blood collection, testing, and support was organized by the main staff of the local blood bank, and all the patients were treated at the same local university hospital (Charité - Universitätsmedizin Berlin, Germany). Blood group typing, antibody screening, and crossmatching were done by standard serological methods as described [18].

The protocol regarding support and transfusion is largely in agreement with national and international guidelines. When blood transfusion is required in emergencies, at least 4 of ten already packed RBC units of blood group 0 will be immediately delivered and, if necessary, as soon as possible transfused independent of serological findings. While all females and if possible young males with ages $\leq 45$ years receive initially $\mathrm{Rh}(\mathrm{D})$-negative units, all other patients receive $\mathrm{Rh}(\mathrm{D})$-positive units unless the blood group of affected patients is known or has been estimated. If patient's plasma contains alloantibodies these antibodies will be considered as soon as possible, but only if antigen-negative RBC units are available. In cases with massive hemorrhage, alloantibodies did not present an absolute contraindication for incompatible blood transfusion if antigen-negative RBC units are not available and as long as bleeding has not been stopped.

The retrospective data analysis was approved by the Institutional Ethical Board and the Institutional Data Protection Board.

\section{Results}

Between 2001 and 2015 a total of 6,109 injured patients received 63,373 uncrossmatched $\mathrm{ABO}$-compatible $\mathrm{RBC}$ units. There was no clinical evidence for the occurrence of any severe acute or delayed HTR due to alloantibodies following transfusion. Antibody screening test was found to be positive in 413 patients (6.8\%). Incompatible blood transfusion could be avoided in 394 patients by the replacement of the initially supplied units by new units lacking the corresponding antigens to the detected antibodies. The remaining 19 patients were transfused with serologically incompatible RBCs (antigens have been detected post transfusion) (Table 1). In 2001, 2003, 2004, 2008, 2013, and 2014 none of the transfused units was incompatible. In the other years incompatibility was related to alloantibodies which are known to cause HTR (Table 1). Only one of these patients (No. 8) who received three incompatible $\mathrm{Rh}(\mathrm{D})$-positive units appeared to have developed an insignificant HTR, since total bilirubin was found to have been moderately increased $(2.2 \mathrm{mg} / \mathrm{dL}$, normal range is below $1 \mathrm{mg} / \mathrm{dL}$ ) and haptoglobin was less than 4 $\mathrm{mg} / \mathrm{dL}$ (normal range $30-200 \mathrm{mg} / \mathrm{dL}$ ). The remaining 4 patients received blood transfusion against alloantibodies which usually do not cause HTR (patient Nos. 3, 4, 5, 18).

In addition, one patient (Table 1, No. 7) intentionally received $\mathrm{Jk}^{\mathrm{a}}$-incompatible $\mathrm{RBC}$ units because no Jk $\mathrm{K}^{\mathrm{a}}$-negative units were available for him. It remained unknown how many incompatible units were transfused.

In summary, none of the 19 patients who received incompatible units has developed clinically significant acute or delayed HTR.

\section{Discussion}

The results obtained here reflect largely those of daily practice in most centers dealing with trauma patients and massive blood transfusion of uncrossmatched RBC units. Trauma is a leading cause of death worldwide and the vast 
Table 1. Incompatible RBCs transfused at the Charité - Universitätsmedizin Berlin between 2001 and 2015

\begin{tabular}{|c|c|c|c|c|c|c|c|c|}
\hline Year & Patient & $\begin{array}{l}\text { Age, } \\
\text { years }\end{array}$ & Gender & Antibodies & $\begin{array}{l}\text { All transfused } \\
\text { units, } N\end{array}$ & $\begin{array}{l}\text { Incompatible } \\
\text { transfused units, } N\end{array}$ & HTR & $\begin{array}{l}\text { Reason for massive } \\
\text { bleeding }\end{array}$ \\
\hline \multirow[t]{2}{*}{2002} & 1 & 45 & M & $\mathrm{D}$ & 10 & 2 & No & Unknown \\
\hline & 2 & 66 & $\mathrm{~F}$ & $\mathrm{~K}, \mathrm{Wr} \mathrm{r}^{\mathrm{a}}$ & 2 & 2 & No & Unknown \\
\hline 2005 & 3 & 58 & $\mathrm{~F}$ & $\mathrm{Kn}$ & 2 & 2 & No & Cholecystectomy \\
\hline \multirow[t]{3}{*}{2006} & 4 & 65 & M & M & 4 & 10 & No & Pancreatic tail resection \\
\hline & 5 & 72 & M & $\operatorname{Le}^{a}$ & 4 & 1 & No & Partial bypass rupture \\
\hline & 6 & 52 & M & $\mathrm{D}$ & 10 & 2 & No & Liver cirrhosis \\
\hline \multirow[t]{2}{*}{2007} & 7 & 57 & $\mathrm{~F}$ & $\mathrm{Jk}^{\mathrm{a}}$ & 14 & Unknown* & No & Retransplantation of liver \\
\hline & 8 & 49 & $\mathrm{~F}$ & $\mathrm{D}$ & 6 & 3 & Delayed and mild & Uterus myomatosus \\
\hline \multirow[t]{5}{*}{2009} & 9 & 67 & M & $\mathrm{D}$ & 12 & 6 & No & Gastrointestinal bleeding \\
\hline & 10 & 78 & $\mathrm{~F}$ & C, D & 30 & $5 C D, 3 \mathrm{D}$ & No & Heart and kidney failure \\
\hline & 11 & 50 & M & $\mathrm{Fy}^{\mathrm{a}}$ & 4 & 1 & No & Infected arterial port \\
\hline & 12 & 48 & $\mathrm{~F}$ & $\mathrm{D}$ & 10 & 1 & No & Thermal ablation \\
\hline & 13 & 43 & M & $J k^{a}$ & 10 & 1 & No & Polytrauma \\
\hline \multirow[t]{2}{*}{2010} & 14 & 67 & $\mathrm{~F}$ & $\mathrm{E}$ & 12 & 8 & No & Small bowel resection \\
\hline & 15 & 48 & $\mathrm{~F}$ & $\mathrm{Jk}^{\mathrm{a}}$ & 31 & 5 & No & Hemipelvectomy \\
\hline \multirow[t]{2}{*}{2011} & 16 & 49 & $F$ & $\mathrm{Jk}^{\mathrm{a}}$ & 20 & 20 & No & Ileocecal resection \\
\hline & 17 & 56 & M & $\mathrm{Lu}^{\mathrm{a}}$ & 40 & 2 & No & Ileocecal resection \\
\hline 2012 & 18 & 56 & M & $\mathrm{Kn}$ & 2 & 2 & No & Pleural empyema \\
\hline 2015 & 19 & 40 & M & D & 10 & 1 & No & Aortic valve replacement \\
\hline
\end{tabular}

HTR, hemolytic transfusion reaction. * The number of units are unknown; however, the frequency of Jk is 0.5 . Therefore, statistically, at least some of the 14 transfused units should have been $\mathrm{Jk}^{\mathrm{a}}$-positive.

majority of patients with massive bleeding may die within a few hours without resuscitation with blood products [1923 ]. Thus, the immediate supply of blood plays a key role in the management of such affected patients, as most hemorrhagic deaths occur within 3-6 h of patients' arrivals [2426]. Pretransfusion compatibility testing of RBCs is obligatory to prevent HTRs. However, this procedure including $\mathrm{ABO}$ and at least $\mathrm{Rh}(\mathrm{D})$ typing, screening for alloantibodies, identification of the specificity of unexpected antibodies that are detected, and compatibility testing between recipient and donor RBCs, may require more than 50 min [27]. Meanwhile, many protocols and recommendations are available to avoid any delay in supporting transfusion of RBCs in emergency cases. Without exception all available protocols recommend the use of uncrossmatched RBCs, at least, until serological testing has been completed. The incidence of alloantibodies is low and the occurrence of severe HTR due to alloantibodies is largely negligible [28-34].

In the presented study alloantibodies were detected in $6.8 \%(n=413)$, and 19 of these patients received incompatible RBCs. Only one of the 19 alloimmunized patients seems to have developed a delayed HTR. This patient received three $\mathrm{Rh}(\mathrm{D})$-incompatible RBC units. Based on a detailed clinical observation, there was no evidence for a significant HTR, i.e., hemoglobinuria or instability of patients' conditions which might be related to HTR. The question whether the documented laboratory parameters total bilirubin and haptoglobin may in fact be related to a mild HTR or rather to the underlying disease (surgery of uterus myomatosus) remains unclear. However, it must be emphasized that the interpretation of laboratory data in such emergency cases with massive bleeding are very difficult due to the following facts: (1) these patients usually receive different and large amounts of infusions leading to a dilution effect on many laboratory parameters, (2) many laboratory parameters are frequently estimated as long as patients' conditions are instable. These parameters usually reflect oxygenation, hemostasis, and coagulation. Specific laboratory parameters related to hemolysis will be investigated only in patients who are suspected to have hemolysis, i.e., hemoglobinuria, and circulatory instability due to transfusion.

The conclusion that the other patients did not appear to have developed hemolysis is based on the fact that treating physicians did not report HTR in a single patient, even in patient No. 8. The report of all transfusion reactions is obligatory according to the transfusion guidelines. From a clinical view, there was no evidence for the development 
Table 2. Incompatible RBC transfusions described in the literature

\begin{tabular}{|c|c|c|c|}
\hline Study (references) & $\begin{array}{l}\text { Transfused patients with } \\
\text { untested RBCs, } N\end{array}$ & $\begin{array}{l}\text { Incompatible transfused } \\
\text { patients, } N\end{array}$ & HTR \\
\hline Schmidt et al., 1988 [35] & 418 & $\begin{array}{l}1 \text { (anti-c) } \\
1(\text { anti-Er })\end{array}$ & $\begin{array}{l}\text { No } \\
\text { No }\end{array}$ \\
\hline Unkle et al., 1991 [36] & 135 & $\begin{array}{l}1\left(\text { anti-Jk }^{\mathrm{b}}\right) \\
2\left(\text { anti-Le }^{\mathrm{a}}\right) \\
1(\text { anti-Sd } \\
3 \text { (unknown) }\end{array}$ & $\begin{array}{l}\text { Delayed and mild } \\
\text { No } \\
\text { No } \\
\text { No }\end{array}$ \\
\hline Meny, 2004 [37] & 2 & $\begin{array}{l}1 \text { (anti-D) } \\
1\left(\text { anti-Fy' },-S,-L e^{b}\right)\end{array}$ & $\begin{array}{l}\text { Yes } \\
\text { Yes }\end{array}$ \\
\hline Murthi et al., 2008 [38] & 1 & $1\left(\right.$ anti-Jk $\left.{ }^{a}\right)$ & Yes \\
\hline Goodell et al., 2010 [39] & 265 & $\begin{array}{l}3 \text { (anti-D) } \\
\left.1 \text { (anti-Jk }^{\mathrm{b}}\right) \\
1 \text { (anti-K, anti-E) } \\
1 \text { (anti-E) } \\
1\left(\text { anti-C, anti-E, anti-Jk }^{\mathrm{a}}\right)\end{array}$ & $\begin{array}{l}\text { No } \\
\text { No } \\
\text { No } \\
\text { No } \\
\text { Yes }\end{array}$ \\
\hline Mulay et al., 2013 [34] & 1,444 & 7 (unknown) & No \\
\hline Fiorellino et al., 2018 [40] & 1 & 1 (anti-Fy and anti-K) & Yes \\
\hline
\end{tabular}

of HTR or any relationship between transfusion and outcome. Ultimately, our results are confirmed by several previous reports (Table 2) [34-40]. Only a few of the latter patients have developed HTR. Unfortunately, it remains unknown whether these patients had massive bleeding during the incompatible transfusion.

There are three possible explanations for the finding that incompatible RBC transfusion may not result in significant HTR: (1) at least one part of the transfused incompatible RBCs will be lost due to the ongoing bleeding, (2) the concentration of alloantibodies may decrease by blood loss per se, and by capturing from the circulation by the transfused incompatible RBCs, which also disappear from the circulation, and (3) the immune system might somewhat be paralyzed by the trauma and/or hemorrhagic shock. Ultimately, several inflammatory cells and cytokines are involved in hemorrhagic shock [41,42]. The phenomenon that incompatible RBC transfusion may not result in significant HTR, independent from minor incompatibilities due to the isoagglutinins anti- $\mathrm{A}$ and anti-B, could often be observed after whole blood transfusions in military settings [43-47]. In addition, only a few incompatible RBC transfusion in the presence of alloantibodies have yet been reported. In case of massive transfusion, only six of the previously published patients who received incompatible RBCs developed HTR (Table 2).

All these findings and the results of our study indicate that the presence of alloantibodies to RBCs should not result in any delay of supplying and/or transfusion of incompatible RBCs, in case of life-threatening bleeding.
However, this statement should remain an exception rather than a general recommendation in transfusion medicine to avoid risk of complications. In addition, further reports dealing with incompatible RBCs in multipleinjured patients will be helpful in the management of such affected patients.

\section{Statement of Ethics}

All research complies with the guidelines for human studies and was conducted ethically in accordance with the World Medical Association Declaration of Helsinki. The retrospective data analysis was approved by the Institutional Ethical Board and the Institutional Data Protection Board.

\section{Conflict of Interest Statement}

The authors have no conflicts of interest to declare.

\section{Funding Sources}

No funding was received for this work from any organization.

\section{Author Contributions}

F.R.: literature search, study design, data collection, data analysis, data interpretation, writing, critical revision. H.S.: data analysis, data interpretation, critical revision. S.E.B.: data collection. C.S.: critical revision. J.S.: critical revision. A.S.: literature search, study design, data interpretation, writing, critical revision. 


\section{References}

1 Poole J, Daniels G. Blood group antibodies and their significance in transfusion medicine. Transfus Med Rev. 2007;21(1):58-71.

2 Hendrickson JE, Tormey CA, Shaz BH. Red blood cell alloimmunization mitigation strategies. Transfus Med Rev. 2014;28(3):137-44.

3 United States Food and Drug Administration. CBER [Internet]. 2012. Available from: www. fda.gov/biologicsbloodvaccines/bloodbloodproducts/(last accessed October 16, 2014).

4 Bolton-Maggs $\mathrm{PH}$, Cohen H. Serious Hazards of Transfusion (SHOT) haemovigilance and progress is improving transfusion safety. $\mathrm{Br} J$ Haematol. 2013;163(3):303-14.

5 Alter HJ, Klein HG. The hazards of blood transfusion in historical perspective. Blood. 2008;112(7):2617-26.

6 Schonewille $\mathrm{H}$, van de Watering LM, Brand A. Additional red blood cell alloantibodies after blood transfusions in a nonhematologic alloimmunized patient cohort: is it time to take precautionary measures? Transfusion. 2006;46(4):630-5.

7 Silvergleid AJ, Wells RF, Hafleigh EB, Korn G, Kellner JJ, Grumet FC. Compatibility test using 51chromium-labeled red blood cells in crossmatch positive patients. Transfusion. 1978;18(1):8-14.

8 Mock DM, Widness JA, Veng-Pedersen P, Strauss RG, Cancelas JA, Cohen RM, et al. Measurement of posttransfusion red cell survival with the biotin label. Transfus Med Rev. 2014;28(3):114-25.

9 Zupanska B. Assays to predict the clinical significance of blood group antibodies. Curr Opin Hematol. 1998;5(6):412-6.

10 Garratty G. Mechanisms of immune red cel destruction, and red cell compatibility testing. Hum Pathol. 1983;14(3):204-12.

11 haematology Icfsi. Recommended method for radioisotope red-cell survival studies. International Committee for Standardization in Haematology. Br J Haematol. 1980;45(4): 659-66.

12 Chapman JF, Elliott C, Knowles SM, Milkins CE, Poole GD, Working Party of the British Committee for Standards in Haematology Blood Transfusion Task F. Guidelines for compatibility procedures in blood transfusion laboratories. Transfus Med. 2004;14(1) 59-73.

13 Vamvakas EC, Blajchman MA. Transfusionrelated mortality: the ongoing risks of allogeneic blood transfusion and the available strategies for their prevention. Blood. 2009; 113(15):3406-17

14 Nance ST, Arndt PA. Review: what to do when all RBCs are incompatible - serologic aspects. Immunohematology. 2004;20(3): 147-60.

15 Shulman IA, Downes KA, Sazama K, Maffei LM. Pretransfusion compatibility testing for red blood cell administration. Curr Opin $\mathrm{He}_{-}$ matol. 2001;8(6):397-404.

16 Weinstein R. 2012 Clinical Practice Guide on Red Blood Cell Transfusion. American Society of Hematology. 2012.
17 Carson JL, Grossman BJ, Kleinman S, Tinmouth AT, Marques MB, Fung MK, et al. Red blood cell transfusion: a clinical practice guideline from the AABB*. Ann Intern Med. 2012;157(1):49-58.

18 Sümnig A, Mayer B, Kiefel V, Greinacher A, Salama A. 'Chameleonic' Serological Findings Leading to Life-Threatening Hemolytic Transfusion Reactions. Transfus Med Hemother. 2015;42(5):340-3.

19 Hoyt DB, Bulger EM, Knudson MM, Morris J, Ierardi R, Sugerman HJ, et al. Death in the operating room: an analysis of a multi-center experience. J Trauma. 1994;37(3):426-32.

20 Sauaia A, Moore FA, Moore EE, Moser KS, Brennan R, Read RA, et al. Epidemiology of trauma deaths: a reassessment. J Trauma. 1995;38(2):185-93.

21 Acosta JA, Yang JC, Winchell RJ, Simons RK, Fortlage DA, Hollingsworth-Fridlund $\mathrm{P}$, et al. Lethal injuries and time to death in a level I trauma center. J Am Coll Surg. 1998;186(5): 528-33.

22 Kauvar DS, Lefering R, Wade CE. Impact of hemorrhage on trauma outcome: an overview of epidemiology, clinical presentations, and therapeutic considerations. J Trauma. 2006; 60(6 Suppl 1):S3-11.

23 Kashuk JL, Moore EE, Johnson JL, Haenel J, Wilson M, Moore JB, et al. Postinjury life threatening coagulopathy: is 1:1 fresh frozen plasma:packed red blood cells the answer? J Trauma. 2008;65(2):261-70, discussion 270-

24 Burman S, Cotton BA. Trauma patients at risk for massive transfusion: the role of scoring systems and the impact of early identification on patient outcomes. Expert Rev Hematol. 2012;5(2):211-8.

25 Peng R, Chang C, Gilmore D, Bongard F. Epidemiology of immediate and early trauma deaths at an urban Level I trauma center. Am Surg. 1998;64(10):950-4.

26 Stanworth SJ, Davenport R, Curry N, Seeney F, Eaglestone S, Edwards A, et al. Mortality from trauma haemorrhage and opportunities for improvement in transfusion practice. Br J Surg. 2016;103(4):357-65.

27 Hooker EA, Miller FB, Hollander JL, Bukowski EM. Do all trauma patients need early crossmatching for blood? J Emerg Med. 1994; 12(4):447-51.

28 Gervin AS, Fischer RP. Resuscitation of trauma patients with type-specific uncrossmatched blood. J Trauma. 1984;24(4):32731.

29 Schwab CW, Shayne JP, Turner J. Immediate trauma resuscitation with type $\mathrm{O}$ uncrossmatched blood: a two-year prospective experience. J Trauma. 1986;26(10):897-902.

30 Lefebre J, McLellan BA, Coovadia AS. Seven years experience with group $\mathrm{O}$ unmatched packed red blood cells in a regional trauma unit. Ann Emerg Med. 1987;16(12):1344-9.

31 Dutton RP, Shih D, Edelman BB, Hess J, Scalea TM. Safety of uncrossmatched type-O red cells for resuscitation from hemorrhagic shock. J Trauma. 2005;59(6):1445-9.
32 Inaba K, Teixeira PG, Shulman I, Nelson J, Lee J, Salim A, et al. The impact of uncrossmatched blood transfusion on the need for massive transfusion and mortality: analysis of 5,166 uncross-matched units. J Trauma. 2008; 65(6):1222-6.

33 Miraflor E, Yeung L, Strumwasser A, Liu TH, Victorino GP. Emergency uncrossmatched transfusion effect on blood type alloantibodies. J Trauma Acute Care Surg. 2012;72(1): 48-52, discussion 52-53.

34 Mulay SB, Jaben EA, Johnson P, Badjie K, Stubbs JR. Risks and adverse outcomes associated with emergency-release red blood cell transfusion. Transfusion. 2013;53(7):141620.

35 Schmidt PJ, Leparc GF, Samia CT. Use of Rh positive blood in emergency situations. Surg Gynecol Obstet. 1988;167(3):229-33.

36 Unkle D, Smejkal R, Snyder R, Lessig M, Ross SE. Blood antibodies and uncrossmatched type O blood. Heart Lung. 1991;20(3):284-6.

37 Meny G. Review: transfusing incompatible RBCs-clinical aspects. Immunohematology. 2004;20(3):161-6.

38 Murthi SB, Dutton RP, Edelman BB, Scalea TM, Hess JR. Transfusion medicine in trauma patients. Expert Rev Hematol. 2008;1(1):99109.

39 Goodell PP, Uhl L, Mohammed M, Powers AA. Risk of hemolytic transfusion reactions following emergency-release RBC transfusion. Am J Clin Pathol. 2010;134(2):202-6.

40 Fiorellino J, Elahie AL, Warkentin TE. Acute haemolysis, DIC and renal failure after transfusion of uncross-matched blood during trauma resuscitation: illustrative case and literature review. Transfus Med. 2018;28(4):31925.

41 Keel M, Trentz O. Pathophysiology of polytrauma. Injury. 2005;36(6):691-709.

42 Cannon JW. Hemorrhagic Shock. N Engl J Med. 2018;378(4):370-9.

43 Spinella PC. Warm fresh whole blood transfusion for severe hemorrhage: U.S. military and potential civilian applications. Crit Care Med. 2008;36(7 Suppl 1):S340-5.

44 Yuan S, Ziman A, Anthony MA, Tsukahara E, Hopkins C, Lu Q, et al. How do we provide blood products to trauma patients? Transfusion. 2009;49(6):1045-9.

45 Nessen SC, Cronk DR, Edens J, Eastridge BJ, Little TR, Windsor J, et al. US Army two-surgeon teams operating in remote Afghanistanan evaluation of split-based Forward Surgical Team operations. J Trauma. 2009;66(4 Suppl 1):S37-47.

46 Spinella PC, Perkins JG, Grathwohl KW, Beekley AC, Holcomb JB. Warm fresh whole blood is independently associated with improved survival for patients with combat-related traumatic injuries. J Trauma. 2009;66(4 Suppl 1):S69-76.

47 Strandenes G, Berséus O, Cap AP, Hervig T, Reade $\mathrm{M}$, Prat $\mathrm{N}$, et al. Low titer group $\mathrm{O}$ whole blood in emergency situations. Shock. 2014(41 Suppl 1):70-5. 